\title{
In vitro antibacterial and antibiotic modifying activity of crude extract, fractions and 3',4',7-trihydroxyflavone from Myristica fragrans Houtt against MDR Gram-negative enteric bacteria
}

Joachim K. Dzotam¹, Ingrid Konga Simo², Gabin Bitchagno², Ilhami Celik ${ }^{4}$ Louis P. Sandjo ${ }^{3}$, Pierre Tane ${ }^{2}$ and Victor Kuete ${ }^{1 *}$

\begin{abstract}
Background: Nutmeg is the seed kernel inside the fruit of Myristica fragrans Houtt. (Myristicaceae). It possesses various pharmacological activities but is used in Cameroon only for its flavor in making cakes. The present study thus aimed to investigate the in vitro antibacterial activity and antibiotic modifying activities of crude seed kernel methanol extract (MFS), fractions (MFSa-e) as well as 3,'4',7-trihydroxyflavone from Myristica fragrans against a panel of multi-drug resistant (MDR) Gram-negative bacteria.

Methods: The modified rapid p-iodonitrotetrazolium chloride (INT) colorimetric assay was used to determine the Minimal Inhibitory Concentration (MIC) and Minimal Bactericidal Concentration (MBC) on the tested bacteria, as well as those of antibiotics in association with the extract and/or isolated compound. Column chromatography was used for the fractionation and purification of the seed kernel extract whilst the chemical structures of compounds were determined using spectroscopic techniques.

Results: Phytochemical investigations lead to the isolation of 3',4',7-trihydroxyflavone from the fraction MFSb. The crude extract showed antibacterial activity with MICs ranging from 32 to $1024 \mu \mathrm{g} / \mathrm{mL}$ on the majority of the 29 tested Gram-negative bacterial strains. Fraction MFSb inhibited the growth of 100\% (29/29) of the tested bacterial strains, as well as the compound 3,4',7-trihydroxyflavone (12/12) with a MIC values ranging from 32 to $1024 \mu \mathrm{g} / \mathrm{mL}$, and 4 to $128 \mu \mathrm{g} / \mathrm{mL}$ respectively. The lowest MIC value $(4 \mu \mathrm{g} / \mathrm{mL})$ was recorded with 3',4,7-trihydroxyflavone against Providencia stuartii ATCC299645 as well as the best MBC value $(16 \mu \mathrm{g} / \mathrm{mL})$ against the same strain. In the presence of Phenylalanine-Arginine- $\beta$-Naphthylamide (PABN), an efflux pumps inhibitor, the activity of the extract increased on $73.33 \%(11 / 15)$ meanwhile that of $3^{\prime}, 4^{\prime}, 7$-trihydroxyflavone increased on $100 \%$ tested bacteria. The compound $3^{\prime}, 4^{\prime}, 7$-trihydroxyflavone potentiated the activity of antibiotics in the majority of the tested bacterial strains.

Conclusion: The results of the present work provide additional information on the use of nutmeg and it major antibacterial component, 3', 4',7-trihydroxyflavone, as a potential drug in the treatment of bacterial infections including multidrug resistant phenotypes.
\end{abstract}

Keywords: 3',4',7-trihydroxyflavone, Antibiotic modifying activity, Cameroon, Gram-negative bacteria, Multidrug-resistance, Myristica fragrans

\footnotetext{
* Correspondence: kuetevictor@yahoo.fr

'Department of Biochemistry, Faculty of Science, University of Dschang, P.O.

Box 67, Dschang, Cameroon

Full list of author information is available at the end of the article
} 


\section{Background}

The use of antibiotics in human heath care or as a preventive measure in animal feed has greatly improved the living conditions of population and animal production. However, it has also gradually contributed to selection of resistant bacteria to different families of antibiotics [1]. Bacterial resistance is of considerable economic importance, and in combination with the undesirable side effects of some synthetic compounds, it becomes necessary and imperative to search for new and cheaper molecules with few side effects [2]. Plants and their derived products have long been used by humans for medicinal purposes. It is estimated today that about $80 \%$ of the world's population uses botanical preparations as medicines to cover their health needs [3]. Besides, promissing new concepts such as efflux pump inhibitors [4] and synergy effect between antibiotics and plant secondary metabolites, are now well developed. Several bioactive spices against MDR Gram-negative bacteria, as well as their ability to potentiate the activity of commonly used antibiotics, have been recently reported. Some of these include: Aframomum citratum [5]; Aframomum melegueta, Scorodophloeus zenkeri, and Tetrapleura tetraptera [6]. In our continuous search for botanicals and phytochemicals to manage bacterial infections involving MDR Gram-negative bacteria, we targeted Myristica fragrans Houtt. (Myristicaceae) commonly known as nutmeg. Nutmeg is mostly used in Cameroon for its flavor in making cake. However, it is used traditionnaly in many other countries for several purposes, including: supporting digestion, relieving headache, stomach ache, insomnia, anti-malarial, aphrodisiac, anti-rheumatoid [7]. Ethanol extract of nutmeg seeds showed high anti-inflammatory effect [8], and more than $70 \%$ growth inhibition against human cancer cell line at a concentration of $100 \mu \mathrm{g} / \mathrm{mL}$ [9], as well as aphrodisiac effect [10]. Methanol extract from this spice caused cell death of jurkat leukemia $\mathrm{T}$ cell line by a mechanism involving SIRT 1 mRNA downregulation [11] and anti-caricinogenic activity [12]. Essential oil obtained from Myristica fragrans seeds has growth inhibition capability of bacterial spores and can be used as food preservative [13]. Previous phytochemical investigation of the plant led to the isolation of several compounds including: benzene derivatives (myristicin, elemicin, safrole) myristic acid, alpha-pinene, terpenes, beta-pinene and trimyristin $[14,15]$, trimyristin, derivatives of neolignans and eugenol [16] and also quercitin [8]. In the present study the bioguided fractionation was undertaken for depth investigation of the antibacterial activity, and antibiotic-modulating effect of methanol extract from Mysristica fragrans seeds.

\section{Methods}

\section{General procedure}

For compound characterization, ElectroSpray ionization mass spectrometry (ESI-MS), nuclear magnetic resonance (NMR) spectra, column chromatography (CC) and thin layer chromatography (TLC) were performed according to previously described protocols [17-19].

\section{Plant material and extraction}

The dried seeds of Myristica fragrans were purchased in march 2015 from Douala central market, Littoral Region of Cameroon. The identification of plant (leaves, bark and seeds) was done at the National Herbarium (Yaounde, Cameroon) where a voucher specimens were deposited under the reference number 60342 HNC (YA). The powdered seeds of $M$. frangrans (1500 g) were macerated in methanol $(\mathrm{MeOH}, 5 \mathrm{~L})$ for $48 \mathrm{~h}$ at room temperature. The extract was then concentrated under reduced pressure to give a semi-solid reddish brown fat residue, (370 g) which constituted the crude extract (MFS). The extract was then kept at $4{ }^{\circ} \mathrm{C}$ until further use.

\section{Isolation and purification of bioactive compounds from the seeds extract of $M$. fragrans}

Part of the crude extract (350 g) was subjected to silica gel column chromatography eluted with gradients of $\mathrm{CH}_{2} \mathrm{Cl}_{2}$-EtOAc then EtOAc- $\mathrm{CH}_{3} \mathrm{OH}$. Seventy fractions of $400 \mathrm{~mL}$ were collected using mixtures of $\mathrm{CH}_{2} \mathrm{Cl}_{2}$-EtOAc $85: 15,70: 30$ and 30:70, evaporated under reduced pressure and gathered on the basis of their TLC profiles into five main fractions coded A-E (A: 1-6; B: 7-32; C: 33-51; D: 52-60; E: 61-70). These fractions were submitted first to antibacterial test against selected strains. For each bacterial species, a reference strain and at least one resistant strain were selected. In regards to the results obtained, fractions $\mathrm{D}(10 \mathrm{~g})$ and $\mathrm{E}(5 \mathrm{~g})$ were not further investigated due to their low activity. Fraction B (10 g) with the most considerable antibacterial activity was separated by a column chromatography over silica gel using a gradient of $\mathrm{CH}_{2} \mathrm{Cl}_{2}$-EtOAc (100:0, 95:5, 90:10, 85:15, $80: 20,75: 25$ and 70:30) to afford seven sub-fractions (FrB1-FrB7). Subfraction FrB4 was further purified over silica gel by isocratic $\mathrm{CH}_{2} \mathrm{Cl}_{2}$-EtOAc (2:98) to give $3^{\prime}, 4^{\prime}, 7$-trihydroxyflavone (12 mg).

\section{Antimicrobial assays}

Chemicals for antimicrobial assay The reference antibiotics tested in the present work were: chloramphenicol (CHL), tetracycline (TET), ciprofloxacin (CIP), streptomycin (STR), erythromycin (ERY) and kanamycin (KAN) obtained from Sigma-Aldrich (St. Quentin Fallavier, France). $p$-Iodonitrotetrazolium chloride $\geq 97 \%$ 
(INT, Sigma-Aldrich) was used as microbial growth indicator meanwhile phenylalanine-arginine- $\beta$-naphthylamide (PAßN) (Sigma-Aldrich) was used as efflux pump inhibitor (EPI).

Microbial strains and culture media A total of 29 Gram-negative bacteria were investigated in this work and included reference (from American Type Culture Collection) and clinical (Laboratory collection) strains of Escherichia coli, Enterobacter aerogenes, Klebsiella pneumoniae, Providencia stuartii and Pseudomonas aeruginosa. Their resistance profiles were previously reported [20]. They were maintained on agar slant at $4{ }^{\circ} \mathrm{C}$ and subcultured on a fresh appropriate agar plates $24 \mathrm{~h}$ prior to any antimicrobial test. The activation of bacteria prior to any assay was done in Mueller Hinton Agar (Sigma) meanwhile antibacterial assays were carried out using Mueller Hinton broth (MHB; Sigma) [21].

Microbial susceptibility testing Minimal inhibitory concentration (MIC) and minimal bactericidal concentration $(\mathrm{MBC})$ of samples against the tested bacteria were determined by microplate dilution method using the rapid INT colorimetric assay according to previously described methods [22] with some modifications [21, 23, 24].

The role of efflux pumps in the susceptibility of Gramnegative bacteria was evaluated by testing the samples (crude extract and isolated compound) in the presence of an efflux pump inhibitor (EPI), the PAßN (at $30 \mu \mathrm{g} / \mathrm{mL}$ ) against fifteen selected MDR phenotypes for the crude extract, and seven for the isolated compound.

To evaluate the potentiating effect of the tested crude extract and compound, a preliminary assay was performed using the association of extract or isolated compound at their various sub-inhibitory concentrations with antibiotics against one of a problematic bacteria, $P$. aeruginosa $\mathrm{PA} 124$. $\mathrm{MIC} / 2$ and $\mathrm{MIC} / 4$ of extract or isolated compound were selected as the best sub-inhibitory concentrations $[6,25]$ and were further used for samples-antibiotics combinations against the selected MDR microorganisms. For each sample-antibiotic association, the fractional inhibitory concentration (FIC) was determined as the ratio of MIC of Antibiotic in combination, versus MIC of Antibiotic alone ( $\mathrm{MIC}_{\text {Antibiotic in combination }}$ / $\left.\mathrm{MIC}_{\text {Antibiotic alone }}\right)$ and the interpretation made as follows: synergistic $(\leq 0.5)$, indifferent (1 to 4$)$, or antagonistic $(>4)$ $[26,27]$. All experiments were done in triplicates.

\section{Results}

Isolated compound

The chemical structure of $3^{\prime}, 4^{\prime}, 7$-trihydroxyflavone from the seeds of $M$. fragrans were elucidated using NMR $\left({ }^{1} \mathrm{H}\right.$ and $\left.{ }^{13} \mathrm{C}\right)$ data, in comparison with the literature [28] (Fig. 1). The ${ }^{1} \mathrm{H}$ NMR, ${ }^{13} \mathrm{C}$ NMR spectra and

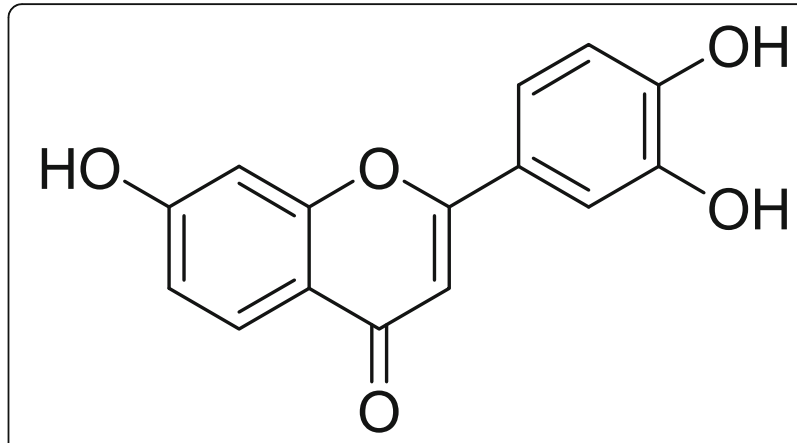

Fig. 1 Chemical structure of 3',4',7-trihydroxyflavone isolated from the seeds of Myristica fragrans Houtt

major chemical shifts of isolated compound are avalaible as Additional file 1. Extract, fractions, and 3',4',7trihydroxyflavone identified in the seeds of $M$. fragrans were tested for their antimicrobial activities and antibiotic-modulating activity on a panel of Gramnegative bacteria. The results are reported in Tables 1 , 2,3 and 4.

\section{Antibacterial activity}

Crude seed extract (MFS), fractions MFSa-e and chloramphenicol were tested on a panel of 29 bacteria. The results summarized in Table 1 reveal selective activities with MIC values ranging from 32 to $1024 \mu \mathrm{g} / \mathrm{mL}$ for MFS against 26/29 (89.65\%) tested bacteria as well as MFSb, MFSc, MFSa, MFSd and MFSe respectively against 29/29 (100\%), 28/29 (96.55\%), 26/29 (89.65\%), $26 / 29(89.65 \%)$ and $5 / 29(13.79 \%)$ tested bacteria.

A keen look at data from Table 1 indicated that the $\mathrm{MBC} / \mathrm{MIC}$ ratios were generally above 4 . The antibacterial activities of $3^{\prime}, 4^{\prime}, 7$-trihydroxyflavone compiled in Table 2 show that this compound inhibited the growth of all the 12 tested bacteria with MIC values ranging from 4 to $256 \mu \mathrm{g} / \mathrm{mL}$.

\section{Role of efflux pumps in the susceptibility of gram-negative bacteria to the tested plant extracts}

Fifteen of the studied MDR bacteria were also tested for their susceptibility to the crude plant extract (MFS), while seven were tested for their susceptibility to $3^{\prime}, 4^{\prime}, 7$-trihydroxyflavone. This was done in the presence of PA $\beta \mathrm{N}$ at $30 \mu \mathrm{g} / \mathrm{mL}$. The results showed that, when combined with the crude extract and isolated compounds, PA $\beta \mathrm{N}$ improves the activity (decrease of MIC values) of MFS, and $3^{\prime}, 4^{\prime}, 7$-trihydroxyflavone on $11 / 15$ (73.33\%), and $7 / 7$ (100\%) of tested MDR strains respectively (Tables 1 and 2).

Effects of the association of the extracts with antibiotics A preliminary study performed against $P$. aeruginosa PA124, allowed us to choose the appropriate subinhibitory concentrations of $\mathrm{MIC} / 2$ and $\mathrm{MIC} / 4$ for 


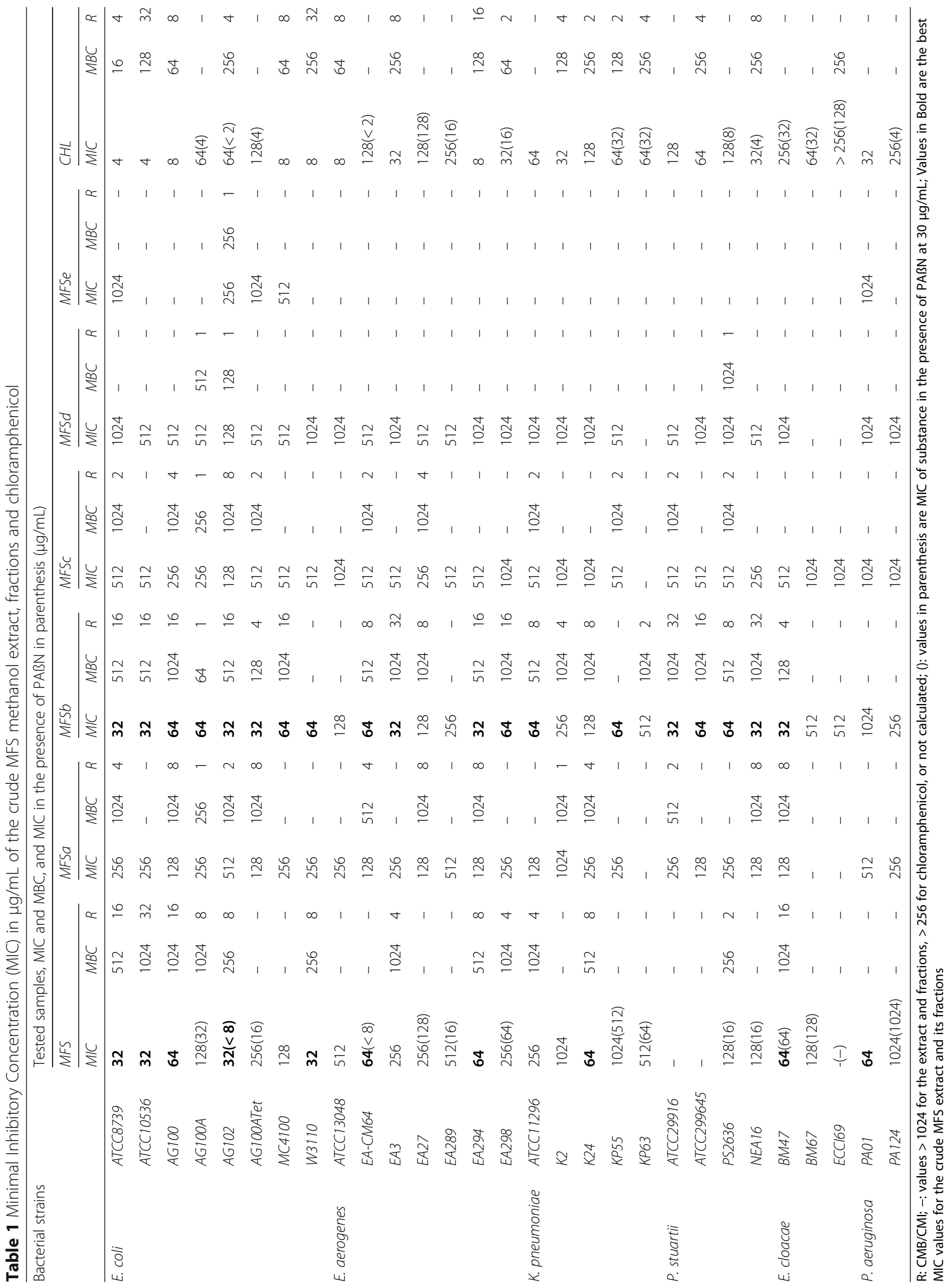


Table 2 Minimal Inhibitory Concentration (MIC) in $\mu \mathrm{g} / \mathrm{mL}$ of isolated compounds and chloramphenicol

\begin{tabular}{|c|c|c|c|c|c|c|c|}
\hline \multirow[t]{3}{*}{ Bacterial strains } & & \multicolumn{6}{|c|}{ Tested samples, MIC and MBC and MIC in the presence ofPABN in parenthesis $(\mu \mathrm{g} / \mathrm{mL})$} \\
\hline & & \multicolumn{3}{|c|}{ 3',4',7-Trihydroxyflavone } & \multicolumn{3}{|c|}{ Chloramphénicol } \\
\hline & & MIC & $M B C$ & $R$ & MIC & $M B C$ & $R$ \\
\hline \multirow[t]{3}{*}{ E. coli } & ATCC8739 & 32 & 256 & 8 & 4 & 16 & 4 \\
\hline & AG102 & $8(<2)$ & 128 & 16 & $16(<2)$ & 64 & 4 \\
\hline & AG100ATet & 64(4) & 128 & 2 & $128(4)$ & 256 & 4 \\
\hline \multirow[t]{3}{*}{ E. aerogenes } & ATCC13048 & 64 & - & - & 8 & 64 & 4 \\
\hline & EA27 & $64(4)$ & - & - & $128(128)$ & - & - \\
\hline & EA289 & $64(32)$ & - & - & 256(16) & - & - \\
\hline \multirow[t]{2}{*}{ K. pneumoniae } & ATCC11296 & 32 & 128 & 4 & 16 & 128 & 8 \\
\hline & KP63 & $128(16)$ & - & - & $64(32)$ & - & - \\
\hline \multirow[t]{2}{*}{ P. stuartii } & ATCC299645 & 4 & 16 & 8 & 8 & 64 & 8 \\
\hline & NEA16 & $32(<2)$ & 128 & 4 & $32(4)$ & 256 & 8 \\
\hline \multirow[t]{2}{*}{ P. aeruginosa } & PA01 & 64 & - & - & - & - & - \\
\hline & PA124 & $128(16)$ & 256 & 2 & - & - & - \\
\hline
\end{tabular}

$\mathrm{R}: \mathrm{CMB} / \mathrm{CMl} ;-$ : values $>256$ or not calculated; (): values in parenthesis are MIC of substance in the presence of PAßN at $30 \mu \mathrm{g} / \mathrm{mL} ; \mathrm{Values}$ in Bold are the best $\mathrm{MIC}$ values for the compounds

further studies. The two samples were combined separately to six antibiotics (CIP, STR, CHL, ERY, KAN and TET) to evaluate their possible synergistic effects. The results summarized in Tables 3 and 4 showed that the synergistic effects were noted with all the tested samples with most of tested antibiotics. The activity of STR increased in the presence of almost all the tested samples at $\mathrm{CMI} / 2$,on at least $60 \%$ of the tested MDR. Also, the $3^{\prime}, 4^{\prime}, 7$-trihydroxyflavone improved the activity of tetracycline and erythromycin on $80 \%$ of the tested bacteria, with FIC values ranging from 0.5 to $<0.062$.

\section{Discussion}

\section{Chemical composition}

We isolated in the present study, a flavonoid ( $3^{\prime}, 4^{\prime}, 7$-trihydroxyflavone) from the dried seeds of $M$. fragrans. Previous phytochemical studies on the same part of this plant revealed that the major chemical constituents are alkyl benzene derivatives (myristicin, elemicin, safrole), myristic acid, $\alpha$-pinene, $\beta$-pinene and trimyristin $[14,15]$. In the present work however, the isolation of a flavonoid from the methanol extract could probably be due to the fact that the purification was guided by the antibacterial activity and hence all fractions and sub-fractions were not explored.

\section{Antibacterial activity of the tested samples}

According to established criteria [29, 30], the antibacterial activity of a plant extract is considered to be significant when the MIC values are below $100 \mu \mathrm{g} / \mathrm{mL}$, moderate when $100 \leq \mathrm{MIC} \leq 625 \mu \mathrm{g} / \mathrm{mL}$ and weak when MIC $>625 \mu \mathrm{g} / \mathrm{mL}$. Consequently, the antibacterial activity of the crude seed extract (MFS) of $M$. fragrans could therefore be considered to be significant, since the MIC values below $100 \mu \mathrm{g} / \mathrm{mL}$ were obtained on the majority of the tested bacteria (Table 1). Fractionation, however yielded samples with sligtly the same activity as the crude extract, and the antibacterial effect could be considered to be moderate for most of them, but significant for the fractions MFSb (see Table 1). In fact, the lowest MIC value $(32 \mu \mathrm{g} / \mathrm{mL})$ was obtained with the crude MFS extract against 4 strains of $E$. coli (ATCC8739, ATCC10536, AG102 and W3110), as well as with the most active fraction MFSb against 9 bacteria strains (E. coli: ATCC8739, ATCC10536, AG102, AG100ATet; E. aerogenes: EA3, EA294; P. stuartii: ATCC29916, NEA16 and E. cloacae BM47). Importantly, the MIC values obtained with the crude MFS extract against E. coli AG102, E. aerogenes EA-CM64, K. pneumoniae K24 and E. cloacae BM47 (Table 1), and the most active fraction MFSb, against. E. coli AG102 and AG100ATet, E. aerogenes EA-CM64, P. stuartii ATCC29916 and PS2636, and E. cloacae BM47 (Table 1), were lower than those of chloramphenicol. It should be highlighted that MFSb had MIC values below $100 \mu \mathrm{g} / \mathrm{mL}$ against 19 of the 29 tested bacteria. The ratio MBC/MIC obtained were generally above 4 , indicating that the studied extracts as well as the active fractions mostly exerted bacteriostatic effects [31]. Also, MIC and MBC values of the reference drug chloramphenicol were also very high $(>64 \mu \mathrm{g} / \mathrm{mL})$ on several pathogens, confirming that most of the bacterial strains used were MDR phenotypes. The activity of compounds is significant when $\mathrm{MIC}<10 \mu \mathrm{g} / \mathrm{mL}$, moderate when 10 $<\mathrm{MIC}<100 \mu \mathrm{g} / \mathrm{mL}$ and low when $\mathrm{MIC}>100 \mu \mathrm{g} / \mathrm{mL}$ 


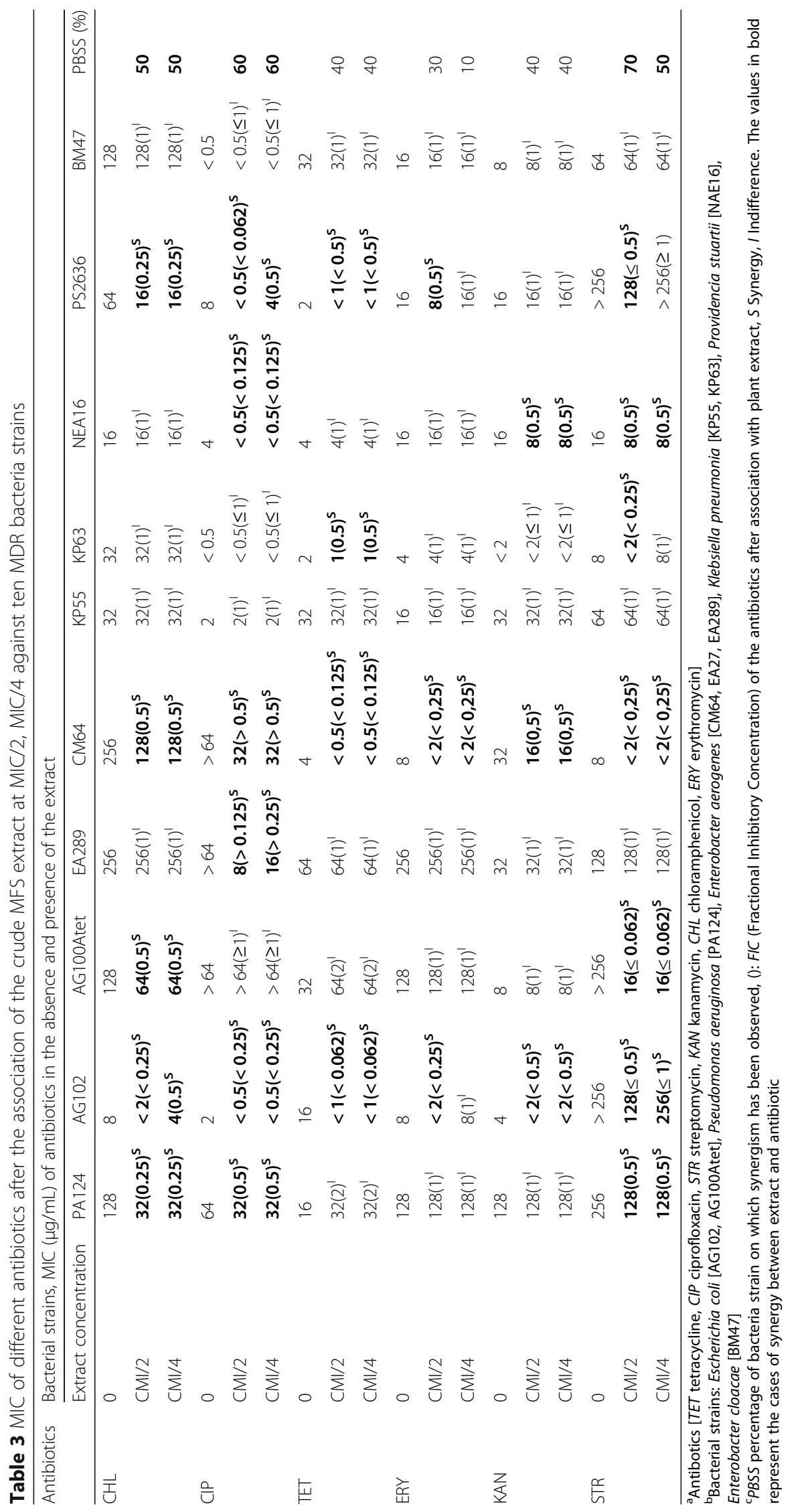


Table 4 MIC of different antibiotics after the association with 3',4',7-Trihydroxyflavone MIC/2, MIC/4 against five MDR bacteria strains

\begin{tabular}{|c|c|c|c|c|c|c|c|}
\hline \multirow[t]{2}{*}{ Antibiotics } & \multicolumn{7}{|c|}{ Bacterial strains, MIC ( $\mu \mathrm{g} / \mathrm{mL})$ of antibiotics in the absence and presence of $3^{\prime}, 4^{\prime}, 7$-Trihydroxyflavone } \\
\hline & Compounds concentration & PA124 & AG100Atet & EA289 & NEA16 & KP63 & PBSS (\%) \\
\hline \multirow[t]{3}{*}{$\mathrm{CHL}$} & 0 & 128 & 8 & 128 & 256 & 256 & \\
\hline & $\mathrm{MIC} / 2$ & $16(0.125)^{\mathrm{S}}$ & $4(0.5)^{5}$ & $128(1)^{1}$ & $256(1)^{1}$ & $256(1)^{1}$ & 40 \\
\hline & $\mathrm{MIC} / 4$ & $32(0.25)^{S}$ & $8(1)^{\prime}$ & $128(1)^{\prime}$ & $256(1)^{\prime}$ & $256(1)^{\prime}$ & 20 \\
\hline \multirow[t]{3}{*}{ CIP } & 0 & 64 & 8 & $>64$ & $>64$ & $>64$ & \\
\hline & $\mathrm{MIC} / 2$ & $32(0.5)^{\mathrm{S}}$ & $4(0.5)^{5}$ & $>64(\geq 1)^{\prime}$ & $>64(\geq 1)^{\prime}$ & $32\left({ }^{<} 0.5\right)^{\mathrm{S}}$ & 60 \\
\hline & $\mathrm{MIC} / 4$ & $64(1)^{1}$ & $8(1)^{\prime}$ & $>64(\geq 1)^{\prime}$ & $>64(\geq 1)^{\prime}$ & $>64(\geq 1)^{1}$ & 00 \\
\hline \multirow[t]{3}{*}{ TET } & 0 & 16 & 16 & 32 & 64 & 4 & \\
\hline & $\mathrm{MIC} / 2$ & $4(0.25)^{S}$ & $<1(<0.062)^{\mathrm{S}}$ & $64(2)^{\prime}$ & $32(0.5)^{S}$ & $<0.5(<0.125)^{\mathrm{S}}$ & 80 \\
\hline & $\mathrm{MIC} / 4$ & $8(0.5)^{5}$ & $<1(<0.062)^{\mathrm{S}}$ & $64(2)^{1}$ & $32(0.5)^{5}$ & $<0.5(<0.125)^{\mathrm{S}}$ & 80 \\
\hline \multirow[t]{3}{*}{ ERY } & 0 & 128 & 8 & 128 & 256 & 8 & \\
\hline & $\mathrm{MIC} / 2$ & $16(0.125)^{S}$ & $4(0.5)^{5}$ & $16(0.5)^{S}$ & $128(0.5)^{\mathrm{S}}$ & $8(1)^{1}$ & 80 \\
\hline & $\mathrm{MIC} / 4$ & $16(0.125)^{\mathrm{S}}$ & $8(1)^{\prime}$ & $128(1)^{\prime}$ & $128(0.5)^{\mathrm{S}}$ & $8(1)^{1}$ & 40 \\
\hline \multirow[t]{3}{*}{ KAN } & 0 & 128 & 4 & 8 & 32 & 32 & \\
\hline & $\mathrm{MIC} / 2$ & $32(0.25)^{\mathrm{s}}$ & $4(1)^{\prime}$ & $4(0.5)^{5}$ & $32(1)^{\prime}$ & $16(0.5)^{S}$ & 60 \\
\hline & $\mathrm{MIC} / 4$ & $64(0.5)^{S}$ & $4(1)^{1}$ & $8(1)^{1}$ & $32(1)^{1}$ & $16(0.5)^{S}$ & 40 \\
\hline \multirow[t]{3}{*}{ STR } & 0 & 256 & $>256$ & $>256$ & 128 & 8 & \\
\hline & $\mathrm{MIC} / 2$ & $16(0.0625)^{\mathrm{S}}$ & $256(<1)^{S}$ & $>256(\geq 1)^{\prime}$ & $128(1)^{\prime}$ & $4(0.5)^{5}$ & 60 \\
\hline & $\mathrm{MIC} / 4$ & $32(0.125)^{S}$ & $>256(\geq 1)^{\prime}$ & $>256(\geq 1)^{\prime}$ & $128(1)^{\prime}$ & $8(1)^{1}$ & 20 \\
\hline
\end{tabular}

${ }^{a}$ Antibotics [TET tetracycline, CIP ciprofloxacin, STR streptomycin, KAN kanamycin, CHL chloramphenicol, ERY erythromycin]

${ }^{b}$ Bacterial strains: Escherichia coli [AG100Atet], Pseudomonas aeruginosa [PA124], Enterobacter aerogenes [EA289], Klebsiella pneumonia [KP63], Providencia stuartii [NAE16]

${ }^{C}$ PBSS percentage of bacteria strain on which synergism has been observed, (): FIC (Fractional Inhibitory Concentration) of the antibiotics after association with compounds, S Synergy, I Indifference; The values in bold represent the cases of synergy between extract and antibiotic

$[29,30]$. On this basis, the activity of compound $3^{\prime}, 4^{\prime}, 7$-trihydroxyflavone could be considered as significant against the strains of E. coli AG102 (MIC of $8 \mu \mathrm{g} / \mathrm{mL}$ ) and P. stuartii ATCC299645 (MIC of $4 \mu \mathrm{g} / \mathrm{mL}$ ) (Table 2).

\section{Role of efflux pumps in the susceptibility of gram-negative} bacteria to the tested extracts

The MDR bacteria strains studied herein overexpressed efflux mechanism, which consist of expelling all toxic compounds (including antibiotics) out of their cytoplasm, preventing them from reaching their intracellular target [32]. In order to restore the intracellular concentration of antibacterials acting on intracellular target, efflux pumps could be blocked by an efflux pump inhibitor (EPI). In fact, in the presence of $P A \beta N(E P I)$, the antibacterial activity of the crude MFS extract as well as that of $3^{\prime}, 4^{\prime}, 7$-trihydroxyflavone has been improved on 11/15 (73,37\%) and $7 / 7(100 \%)$ respectively, on the tested MDR. These results suggested that the crude MFS extract as well as its active constituent, might be considered as substrates for efflux pumps, indicating that they may have an intracellular target [33].
Effects of association of extracts with antibiotics

The loss of efficacy of commonly used antibiotics against MDR pathogens leads to the search of safety ways to improve, or at least to restore their activity. The combination of antibiotics with natural compounds is one of these strategies. In the present work, synergy was observed between the crude MFS extract, as well as its isolated compound with at least one of the six tested antibiotics against at least $50 \%$ of the MDR bacteria strains. A keen look from the results (Table 4) shows that 3',4',7-trihydroxyflavone has improved the activity of at least $70 \%$ of the tested antibiotics on more than $70 \%$ tested bacterial strains with FIC values, ranging mostly from 0.5 to $<0.0625$. These results suggest that this compound could be considered as a potential efflux pump inhibitor [27].

\section{Conclusion}

The present work demonstrated the important antibacterial activity of MFS crude extract and one of its derived compound, 3',4',7-trihydroxyflavone against MDR phenotypes. These two samples deserve further studies to develop new phytomedicines to manage bacterial infections involving MDR organisms. 


\section{Additional file}

Additional file 1: NMR data of $3^{\prime}, 4^{\prime}, 7$-trihydroxyflavone. ${ }^{1} \mathrm{H} \mathrm{NMR},{ }^{13} \mathrm{C}$ NMR spectra and chemical shifts of isolated compound. (DOCX $453 \mathrm{~kb})$

\section{Abbreviations}

ATCC: American Type Culture Collection; CC: Column Chromatography; CFU: Colony forming unit; CHL: Chloramphenicol; CIP: Ciproflxacin; DMSO: Dimethyl sulfoxide; E. aerogenes: Enterobacter aerogenes; E. cloacae: Enterobacter cloacae; E. coll: Escherichia coli; ERY: Erythromycin; ESIMS: ElectroSpray Ionization Mass Spectrometry; INT: p-iodonitrotetrazolium chloride; K. pneumoniae: Klebsiella pneumoniae; KAN: Kanamycin; MBC: Minimal bactericidal concentration; MDR: Multidrug resistant; MHB: Mueller Hinton Broth; MIC: Minimal inhibitory concentration; NHC: National Herbarium of Cameroon; NMR: Nuclear Magnetic Resonance; P. aeruginosa: Pseudomonas aeruginosa; P. stuartii: Providencia stuartii; RA: Reference antibiotic; SRPC: Scientific Research Projects Commission; STR: Streptomycin; TET: Tetracyclin; TLC: Thin Layer Chromatography

\section{Acknowledgements}

Authors are thankful to; the Cameroon National Herbarium specially Mr. NGANSOP T. Eric for identification of plants, and Mr. Nangwat Claude for language editing. IC would like to thank the SRPC for funding the NMR analysis.

\section{Funding}

Part of the research was funded by the Scientific Research Projects Commission (SRPC; Grant 1306F110) of Anadolu University, Eskisehir, Turkey.

\section{Availability of data and materials}

All data generated or analysed during this study are included in this published article and its supplementary information files.

\section{Authors' contributions}

JKD, IKS and GB carried out the study; VK designed the experiments. JKD, GB and VK wrote the manuscript; VK supervised the work and provided the bacterial strains; IC, LPS and PT contributed to structural determination; all authors read and approved the final manuscript.

\section{Ethics approval and consent to participate}

Not applicable in this section.

\section{Consent for publication}

Not applicable in this section.

\section{Competing interests}

VK is a Section Editor of BMC Complementary and Alternative Medicine.

\section{Publisher's Note}

Springer Nature remains neutral with regard to jurisdictional claims in published maps and institutional affiliations.

\section{Author details \\ 'Department of Biochemistry, Faculty of Science, University of Dschang, P.O Box 67, Dschang, Cameroon. '2Department of Chemistry, Faculty of Science, University of Dschang, Dschang, Cameroon. ${ }^{3}$ Department of Pharmaceutical Sciences, CCS, Universidade Federal de Santa Catarina, Florianópolis, Santa Catarina 88040-900, Brazil. ${ }^{4}$ Department of Chemistry, Faculty of Science, Anadolu University, Eskişehir, Turkey.}

Received: 5 October 2017 Accepted: 8 January 2018

Published online: 15 January 2018

\section{References}

1. Harbottle H, ThakuR S, Zhao S, White DG. Genetics of antimicrobial resistance. Anim Biotechnol. 2006:17:111-24.

2. Amgad AA, Martin RPJ, Ismail MM, Abdelkareem MA, Ahmad MA, Mohamed EH. Antimicrobial activities of seed extracts of mango(MangiferaindicaL.) Adv Microbiol. 2012;2:571-6.
3. Kadhim MI, Rana KN, Amaal SA. Antibacterial activity of nutmeg (Myristicafragrans) seed extracts against some pathogenic bacteria. J Al-Nahrain Univ. 2013;16(2):188-92.

4. Newmann D, Cragg GM. Natural products as sources of new drugs over the last 25 years. J Nat Prod. 2007;70:461-77.

5. Fankam AM, Kuete $V$, Voukeng I, Kuiate J-R, Pagès J-M. Antibacterial activities of selected Cameroonian spices and their synergistic effects with antibiotics against multidrug-resistant phenotypes. BMC Complement Altern Med. 2011;11:104.

6. Voukeng I, Kuete V, Dzoyem J-P, Fankam AG, Noumedem JAK, Kuiate J-R, et al. Antibacterial and antibiotic-potentiation activities of the methanol extract of some Cameroonian spices against gram-negative multi-drug resistant phenotypes. BMC Complement Altern Med. 2012;5:299.

7. Nagja T, Vimal K, Sanjeev A. Myristica Fragrans: a comprehensive review. Int J Pharm Pharm Sci. 2016;8(2):27-30.

8. Dewi K, Widyarto B, Erawijantari PP, Widowati W. In vitro study of Myristica fragrans seed (nutmeg) ethanolic extract and quercetin compound as an anti-inflammatory agent. Int J Res Med Sci. 2015:3:2303-10.

9. Prakash E, Gupta DK. Cytotoxic activity of ethanolic extract of Myristica fragrans (Houtt) against seven human cancer cell lines. UJFNS. 2013;1:1-3.

10. Tajuddin AS, Latif A, Qasmi IA. Aphrodisiac activity of $50 \%$ ethanolic extracts of Myristica fragrans Houtt. (nutmeg) and Syzygium aromaticum (L) Merr. \& Perry. (clove) in male mice: a comparative study. BMC Complement Altern Med. 2003;20:3-6.

11. Jannu LN, Hussain SP, Rao AR. Chemopreventive action of mace (Myristica fragrans, Houtt) on DMBA-induced papilloma genesis in the skin of mice. Cancer Lett. 1991;56:59-63.

12. Murcia MA, Egea I, Romojaro F, Parras P, Jiménez AM, Martínez-Tomé M Antioxidant evaluation in dessert spices compared with common food additives. Influence of irradiation procedure. J Agric Food Chem. 2004;52:1872-81.

13. Valero M, Salmerón MC. Antibacterial activity of 11 essential oils against Bacillus cereus in tantalized carrot broth. Int J Food Microbiol. 2003;85:73-81.

14. Qiu Q, Zhang G, Sun X, Liu X. Study on chemical constituents of the essential oil from Myristica fragrans Houtt. By supercritical fluid extraction and steam distillation. Zhong Yao Cai. 2004:27:823-6.

15. Yang XW, Huang X, Ahmat M. New neolignan from the seed of Myristica fragrans. Zhongguo Zhong Yao Za Zhi. 2008:33:397-402.

16. Radwan MM, Tabanca N, Wedge D, Tarawneh AH, Cutler SJ. Antifungal compounds from turmeric and nutmeg with activity against plant pathogens. Fitoterapia. 2014;99:341-6.

17. Tankeo SB, Damen F, Sandjo LP, Celik I, Tane P, Kuete V. Antibacterial activities of the methanol extracts, fractions and compounds from Harungana madagascariensis lam. Ex Poir. (Hypericaceae). J. Ethnopharmacol. 2016;190:100-5.

18. Kuete V, Dongmo Mafodong FL, Celik I, Fobofou SAT, Ndontsa BL, Karaosmanoğlu $\mathrm{O}$, et al. In vitro cytotoxicity of compounds isolated from Desbordesia glaucescens against human carcinoma cell lines. South Afr J Bot. 2017:111:37-43.

19. Voukeng IK, Nganou BK, Sandjo LP, Celik I, Beng VP, Tane P, et al, Antibacterial activities of the methanol extract, fractions and compounds from Elaeophorbia drupifera (Thonn.) Stapf. (Euphorbiaceae). BMC Complement Altern Med. 2017:17:28.

20. Lacmata ST, Kuete V, Dzoyem JP, Tankeo SB, Teke GN, Kuiate J-R, et al. Antibacterial activities of selected Cameroonian plants and their synergistic effects with antibiotics against bacteria expressing MDR phenotypes. J Evid Based Complement Alternat Med. 2012:2012:623723.

21. Kuete V, Wabo GF, Ngameni B, Mbaveng AT, Metuno R, Etoa F-X, Ngadjui $B T$, Beng VP, Meyer JJ, Lall N. Antimicrobial activity of the methanolic extract, fractions and compounds from the stem bark of Irvingia gabonensis (Ixonanthaceae). J Ethnopharmacol. 2007;114:54-60.

22. Eloff JN. A sensitive and quick microplate method to determine the minimal inhibitory concentration of plant extracts for bacteria. Planta Med. 1998:64:711-3.

23. Kuete $V$, Mbaveng TA, Tsaffack M, Beng PV, Etoa F-X, Nkengfack AE, Meyer M, Lall N. Antitumor, antioxydant and antimicrobial activities of Bersama engleriana. J Ethnopharmacol. 2008:115:494-501.

24. Kuete V, Nana F, Ngameni B, Mbaveng AT, Keumedjio F, Ngadjui BT. Antimicrobial activity of the crude extract, fractions and compounds from stem bark of Ficus ovata (Moraceae). J Ethnopharmacol. 2009;124:556-61.

25. Dzotam KJ, Touani KF, Kuete V. Antibacterial and antibiotic-modifying activities of three food plants (Xanthosoma mafaffa, Moringa oleifera and Passiflora edulis) against multidrug-resistant (MDR) gram-negative bacteria. BMC Complement Altern Med. 2016;16:1-8. 
26. Coutinho HD, Vasconcellos A, Freire-Pessôa HL, Gadelha CA, Gadelha TS, Almeida-Filho GG. Natural products from the termite Nasutitermes corniger lower aminoglycoside minimum inhibitory concentrations. Pharmacogn Mag. 2010:6:1-4.

27. Braga LC, Leite AAM, Xavier KGS, Takahashi JA, Bemquerer MP, Chartone Souza $E$, et al. Synergic interaction between pomegranate extract and antibiotics against Staphylococcus aureus. Can J Microbiol. 2005;51:541-7.

28. Junior GMV, de Sousa M, Cleyton M, Cavalheiro AJ, JHG L, Chaves MH.

Phenolic derivatives from fruits of Dipteryx lacunifera Ducke and evaluation of their antiradical activities. Helv Chim Acta. 2008;91:2159-67.

29. Kuete V. Potential of Cameroonian plants and derived products against microbial infections: a review. Planta Med. 2010;76(14):1479-91.

30. Kuete V, Efferth T. Cameroonian medicinal plants: pharmacology and derived natural products. Front Pharmacol. 2010;1:123.

31. Gatsing D, Adoga Gl. Antisalmonellal activity and phytochemical screening of various parts of Cassia petersiana (cesulpiniaceae). Res J Microbiol. 2007;2:876-80.

32. Van Bambeke F, Pagès J-M, Lee VJ. Inhibitor of bacterial efflux pumps as adjuvants in antibacterial therapy and diagnostic tools for detection of resistance by efflux. Front Anti-Infect Drug Discov. 2010;1:1-34.

33. Mahamoud A, Chevalier J, Alibert-Franco S, Kern WW, Pagès J-M. Antibiotic efflux pumps in gram-negative bacteria: the inhibitor response strategy. J Antimicrob Chemother. 2007:59:1223-9.

\section{Submit your next manuscript to BioMed Central} and we will help you at every step:

- We accept pre-submission inquiries

- Our selector tool helps you to find the most relevant journal

- We provide round the clock customer support

- Convenient online submission

- Thorough peer review

- Inclusion in PubMed and all major indexing services

- Maximum visibility for your research

Submit your manuscript at www.biomedcentral.com/submit

) Biomed Central 